\title{
DETERMINATION SUBSURFACE ROCKS USING RESISTIVITY GEOELECTRICITY IN PAMAH PAKU KUTAMBARU LANGKAT REGENCY
}

\author{
Rita Juliani dan Hengki Sembiring*
}

Jurusan Fisika, Fakultas Matematika dan Ilmu Pengetahuan Alam, Universitas Negeri Medan, Indonesia

Diterima Oktober 2014; Disetujui November 2014; Dipublikasikan Desember 2014

\begin{abstract}
Abstrak
Telah dilakukan penelitian geolistrik untuk menentukan batuan bawah permukaan di daerah Pamah Paku Kutambaru Kabupaten Langkat. Penelitian ini bertujuan untuk mengetahui jenis dan penyebaran batuan bawah permukaan berdasarkan nilai resistivitasnya di daerah Pamah Paku Kutambaru Kabupaten Langkat. Penentuan jenis batuan bawah permukaan dilakukan dengan menggunakan alat geolistrik ARES (Automatic Resistivity System) dengan metode Schlumberger sebanyak 12 lintasan dan panjang lintasannya 155 meter. Nilai resistivitas bawah permukaan diolah menggunakan software Res2Dinv didapatkan penampang dua dimensi. Penyebaran batuan dilakukan dengan menggunakan software surfer8 untuk mengetahui penyebarannya hingga kedalaman 28 meter. Hasil penelitian geolistrik menunjukkan terdapat batu gamping di kedalaman 15 meter hingga 28 meter dengan nilai resistivitas $500 \Omega \mathrm{m}$ hingga $10000 \Omega \mathrm{m}$. Dari permukaan hingga kedalaman 10 meter dengan nilai resistivitas antara $100 \Omega \mathrm{m}$ hingga $500 \Omega \mathrm{m}$ didominasi oleh batu tufa.
\end{abstract}

Kata Kunci: Pamah Paku, Geolistrik, Res2dinV, Surfer8, Batu gamping

How to Cite Rita Juliani dan Hengki Sembiring, (2015), Determination Subsurface Rocks Using Resistivity Geoelectricity In Pamah Paku Kutambaru Langkat Regency, Jurnal Einsten Prodi Fisika FMIPA Unimed, 3 (2): 8-13.

\footnotetext{
*Corresponding author:

E-mail : hengki.sembiring@yahoo.com
}

p-ISSN : I2338 - 1981 


\section{PENDAHULUAN}

Indonesia memiliki hasil alam yang melimpah di bawah permukaan bumi berupa emas, perak, tembaga dan batuan. Batuan merupakan benda alam penyusun utama bumi dan kumpulan dari satu atau lebih mineral, bahan organik serta bahanbahan vulkanik yang banyak dibutuhkan dan digunakan untuk kehidupan manusia. Batuan terbentuk dari kumpulan magma yang membeku di permukaan bumi dan berakhir menjadi berbagai jenis batuan diantaranya batuan sedimen. Batuan sedimen adalah batuan yang terbentuk dari akumulasi material hasil perombakan batuan yang sudah ada sebelumnya atau hasil aktivitas kimia maupun organisme yang diendapkan lapis demi lapis pada permukaan bumi yang mengalami sedimentasi. Batuan sedimen berjumlah 5\% dari seluruh batuan-batuan yang terdapat di kerak bumi yang terdiri dari batu lempung $15 \%$, batu pasir 5\% dan batu gamping kirakira 80\%. Menurut Endarto (2005) batu gamping merupakan golongan batuan sedimen yang berasal dari sisa-sisa organisme laut seperti kerang, siput laut, dan koral yang sudah mati. Batu gamping tersebar hampir di setiap pulau di seluruh Indonesia. Hampir semua daerah yang memiliki batu gamping memiliki bentangan alam kars. Daerah yang memiliki batu gamping tidak semua berkembang dengan baik menjadi bentangan kars dan bentangan alam kars di setiap daerah memiliki bentukan yang khas. Sumatera Utara memiliki penyebaran batu gamping yang umumnya terletak pada kawasan hutan lindung, hutan produksi dan hutan konservasi seperti yang terletak dikawasan hutan lindung daerah Kabupaten Langkat di Taman Nasional Gunung Lauser (TNGL). Daerah Pamah Paku dengan koordinat UTM 419371 - $420118 \mathrm{mN}$ dan 366001 $366238 \mathrm{mE}$ merupakan daerah yang berbatasan langsung dengan Hutan Nasional Gunung Lauser. Daerah Pamah Paku memiliki kondisi alam karst dengan sumber daya mineral berupa batu gamping. Mengidentifikasi jenis sumber daya mineral bawah permukaan dapat digunakan metode geofisika. (Pohan, 2009)

Metode geolistrik bertujuan untuk memperkirakan formasi batuan bawah permukaan terutama kemampuannya untuk menghantarkan atau menghambat listrik (konduktivitas atau resistivitas) dengan cara mengalirkan sumber ke suatu beban listrik sehingga besarnya resistansi dapat diperkirakan berdasarkan besarnya potensial sumber dan besarnya arus yang mengalir.

\section{METODE PENELITIAN}

Penelitian dilaksanakan di daerah Pamah Paku Kutambaru Kabupaten Langkat dengan menggunakan alat Geolistrik ARES. Data penentuan grid daerah survey menggunakan Global Position System (GPS) map 76CSx dan pengukuran menggunakan geolistrik dilakukan dengan konfigurasi Schlumberger. Data yang diperoleh diolah dengan menggunakan software Res2dinv sehingga diperoleh model penampang dua dimensi sepanjang lintasan. Teknik analisis dan interpretasi data dari geolistrik dilakukan dengan komputer menggunakan software Res2Dinv sehingga diperoleh model penampang dua dimensi. Software Res2dinv merupakan program yang dibuat untuk menghitung serta menggambarkan harga resistivitas dari hasil perhitungan di lapangan. Dengan memasukkan data yang ada yaitu nilai arus dan beda potensial, harga resistivitanya dapat terlihat langsung dengan memiliki perbedaan warna pada setiap lapisan.

Setiap hasil inversi di delapan belas titik pengukuran dianalisa dan dibandingkan dengan menggunakan harga resistivitas material batuan menurut Milsom (2003). Interpretasi dari batuan tersebut berbeda disetiap lintasan karena nilai resistivitas yang berbeda-beda di seluruh lintasan. Analisa seluruh lintasan menggunakan software surfer 8 yang dapat menampilkan kontur bawah permukaan sesuai dengan nilai resistivitasnya sehingga kontur yang ditampilkan dapat digunakan 
sebagai estimasi luasan batu gamping yang ada di setiap kedalaman 5 meter, 10 meter, 15 meter, 20 meter, 25 meter dan 28 meter.

\section{HASIL DAN PEMBAHASAN}

Daerah yang diteliti memiliki ketinggian sekitar 360 dpl hingga 540 dpl. Sungai ketuken dan sungai Kalimbalang mengairi daerah tersebut dan sebelah selatan dan timur daerah penelitian berbatasan langsung dengan hutan Taman Nasional Gunung Leuser serta terdapat di beberapa tempat singkapan batu gamping yang besar di daerah tersebut.

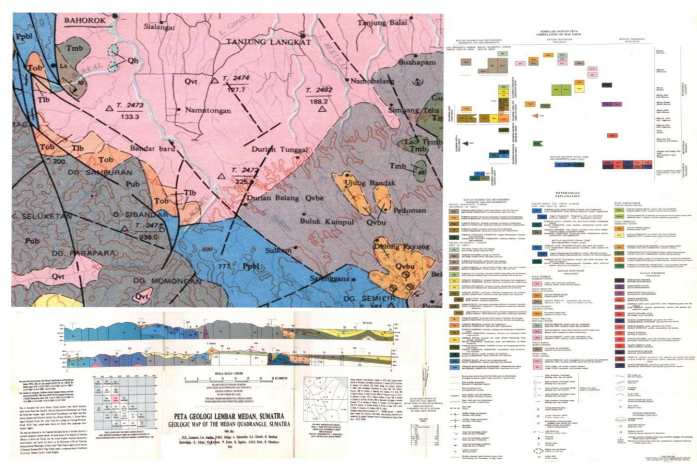

Gambar 1. Peta Geologi Daerah Penelitian (Cameron et al, 1982)

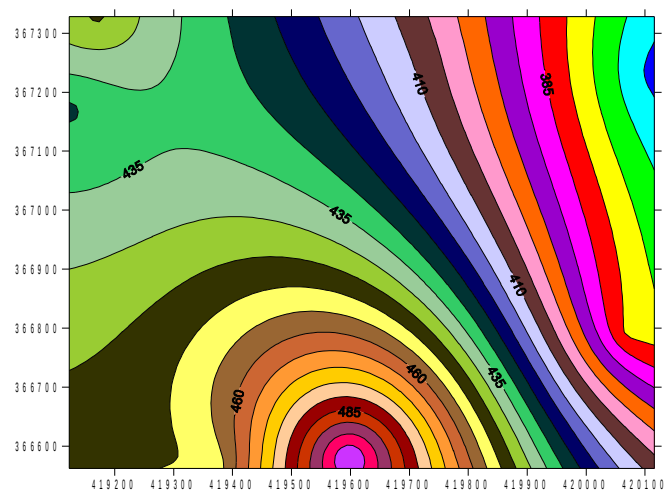

Gambar 2. Kontur daerah penelitian

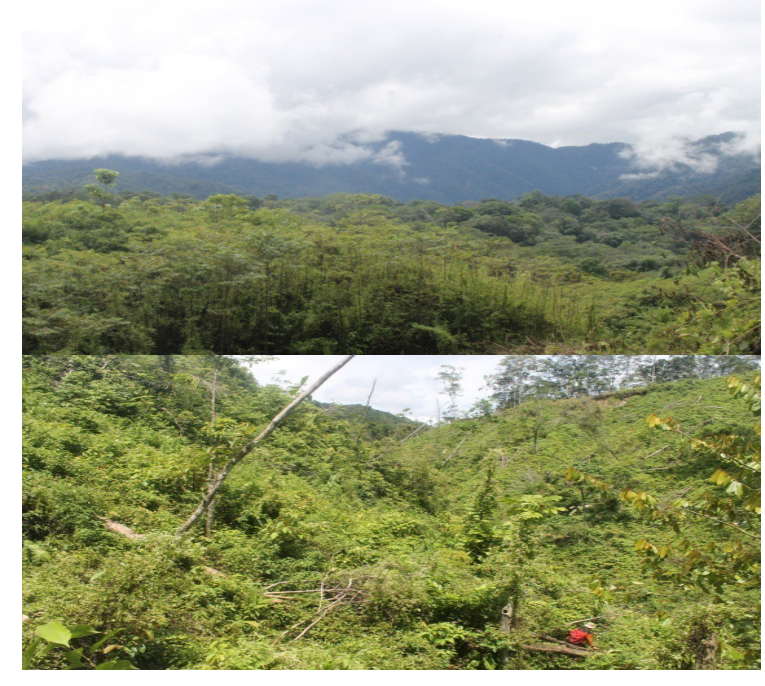

Gambar 3. Morfologi Daerah Penelitian

Daerah pengukuran umumnya menaik, menurun, bergelombang serta jurang (Gambar 3). Hasil penggridan data lapangan menggunakan program surfer8 berdasarkan ketinggian permukaan di delapan daerah pengukuran yang didapat mengunakan GPS. Hasil yang ditampilkan berupa kontur permukaan pengukuran (Gambar 2).

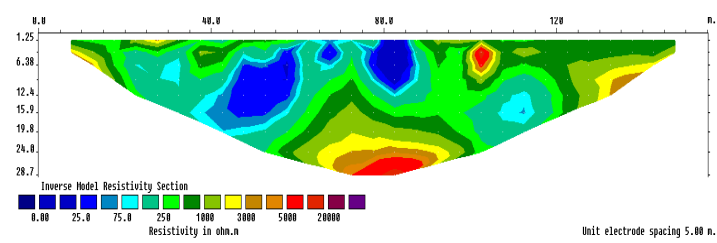

(a)

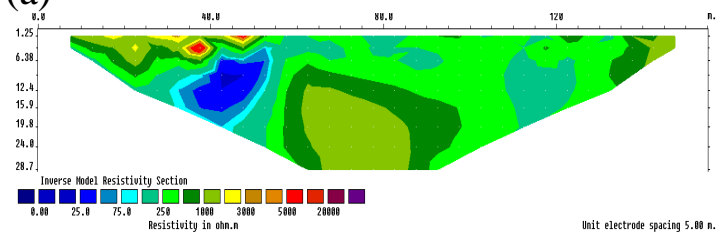

(b)

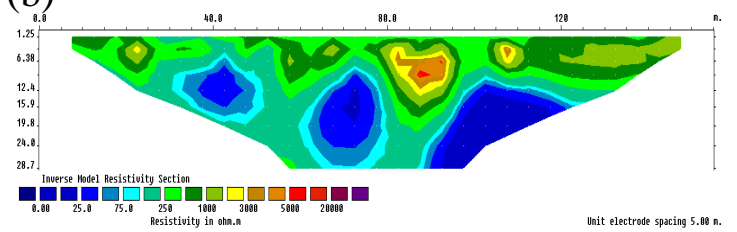

(c)

Gambar 4. Penampang dua dimensi line1 (a)T14 (b) T8 (c) T3

Berdasarkan gambar penampang dua dimensi pada line 1, nilai resistivitasnya berkisar $0 \Omega \mathrm{m}$ sampai dengan $38000 \Omega \mathrm{m}$. 
Color map pada penampang dua dimensi line3 terdapat 17 warna sebagai representasi dari nilai resistivitas batuan bawah permukaan. Lintasan pengambilan data dilakukan dengan arah Utara ke Selatan dengan panjang jarak pengukuran 155 meter dan pada linel merupakan lintasan berbentuk horizontal. Pada kedalaman 5 meter sepanjang lintasan didominasi oleh batu gamping dengan nilai resistivitas antara $500 \Omega \mathrm{m}$ hingga $5000 \Omega \mathrm{m}$ pada pengukuran di titik T3, T2 dan T1. Lapisan di kedalaman 10 meter terdapat nilai resistivitas antara $50 \Omega \mathrm{m}$ hingga 500 $\Omega m$ yang diinterpretasikan sebagai batu tufa di titik T3 dan T1 sedangkan keterdapatan batu gamping yaitu di tititk T2. Pada titik pengukuran T2 dan titik T1 di kedalaman 15 meter hingga di kedalaman 28 meter umumnya terdapat batu gamping dengan nilai resistivitasnya antara $500 \Omega \mathrm{m}$ hingga $10000 \Omega \mathrm{m}$. Hal tersebut dikuatkan juga oleh referensi Milsom (2003) yang menyatakan batu gamping memiliki nilai resistivitas antara $500 \Omega \mathrm{m}$ hingga $10000 \Omega \mathrm{m}$. Titik pengukuran $\mathrm{T} 3$ di kedalaman 15 meter hingga 28 meter didominasi oleh batu tufa dengan nilai resistivitas berkisar $25 \Omega \mathrm{m}$ hingga $500 \Omega \mathrm{m}$. Keterdapatan potensi air bawah tanah telihat dari nilai resistivitas rendah di setiap titik pengukuran yang di duga sebagai batu yang mempunyai lorong penampung air dan memiliki ronggarongga kecil

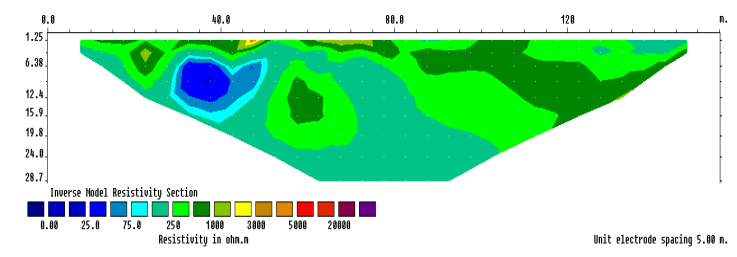

(a)

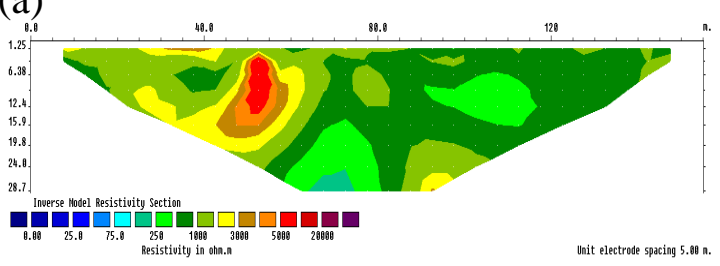

(b)
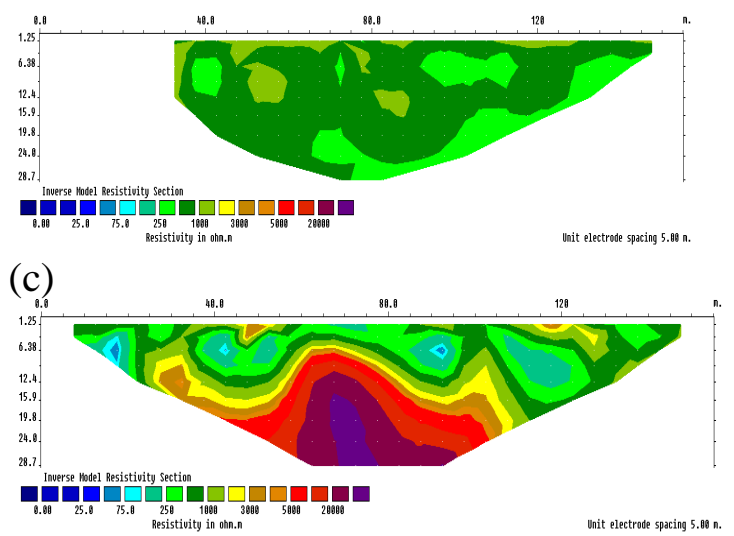

(d)

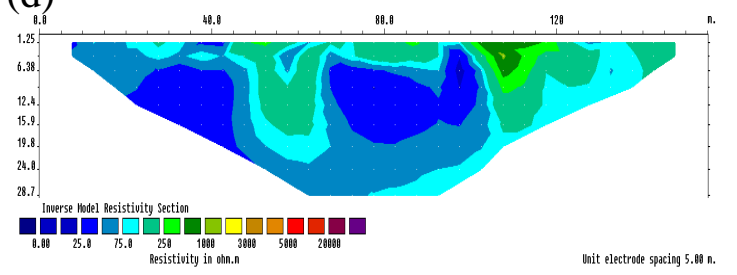

(e)

Gambar 5. Penampang dua dimensi line 2
(a) $\mathrm{T} 16$ (b) $\mathrm{T} 15$ (c) $\mathrm{T} 12$ (d) $\mathrm{T} 17$ (e) $\mathrm{T} 1$

Pada line2, lintasan pengambilan data dilakukan dengan arah Utara ke Selatan dan pada line 4 merupakan lintasan berbentuk horizontal. Pada kedalaman 5 meter sepanjang lintasan didominasi oleh batu gamping dengan nilai resistivitas antara $518 \Omega \mathrm{m}$ hingga $5583 \Omega \mathrm{m}$ pada pengukuran di titik T6, T5, T4 dan T7 sedangkan pada T8 terdapat tufa di sekitar permukaan hingga kedalaman 5 meter yang memiliki nilai resistivitas $100 \Omega \mathrm{m}$ hingga $500 \Omega \mathrm{m}$. Lapisan di kedalaman 10 meter terdapat juga batu gamping tetapi hanya di titik T6 dan T5 sedangkan T8, T4, T7 dengan nilai resistivitas antara $50 \Omega \mathrm{m}$ hingga $500 \Omega \mathrm{m}$ yang diinterpretasikan sebagai batu tufa. Pengukuran di titik T1 pada kedalaman 15 meter hingga 28 meter didominasi oleh batu lempung dan air tanah dengan nilai resistivitas $25 \Omega \mathrm{m}$ hingga 100 $\Omega \mathrm{m}$. Pada titik T4 mempunyai lapisan batu tufa pada kedalaman 15 meter hingga 28 meter dengan nilai resistivitas $100 \Omega \mathrm{m}$ hingga $500 \Omega \mathrm{m}$ sedangkan pada T6, T5 dan T7 merupakan lapisan batu gamping dengan nilai resistivitas $500 \Omega \mathrm{m}$ hingga $10000 \Omega \mathrm{m}$. 


\section{Analisa Lintasan}

Hasil dari pengambilan dan pengolahan data dari lintasan pertama hingga kedelapan dapat diperoleh lapisanlapisan batuan penyusun. Pendugaan adanya batu gamping di daerah pengukuran didukung dari hasil nilai resistivitas yang diperoleh dan kondisi geologi daerah tersebut yang banyak terdapat singkapan batu gamping. Data yang diperoleh akan dianalisis menggunakan surfer8 dan akan diambil per kedalaman untuk keseluruhan lintasan pengukuran. Titik pengukuran sebanyak delapan yang dapat menggambarkan jenis batuan pada daerah tersebut dan menggambarkan penyebaran batuan per kedalaman. Kedalaman yang akan ditampilkan adalah kedalaman 5 meter, 10 meter, 15 meter, 20 meter, 25 meter dan 28 meter.

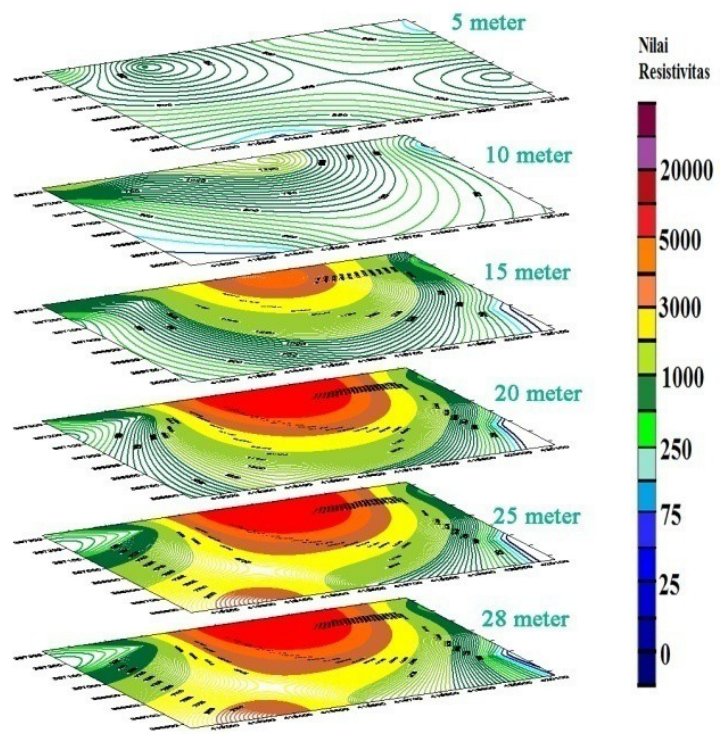

Gambar 6. Hasil kontur kedalaman 5 meter hingga 28 meter menggunakan surfer8

Analisa jenis batuan yang terdapat pada kedalaman 5 meter hingga 28 meter seluruh lintasan pengukuran terlihat pada gambar 4.12 yang menunjukkan bahwa sebagian besar jenis batuan yang terdapat pada lapisan tersebut merupakan batu tufa dengan nilai resistivitas dibawah $500 \Omega \mathrm{m}$ yang direpresentasikan dengan warna putih. Batu gamping pada setiap lapisan ditunjukkan oleh warna hijau tua hingga merah yang mempunyai nilai resistivitas antara $500 \Omega \mathrm{m}$ hingga $10000 \Omega \mathrm{m}$ dan secara keseluruhan batu gamping tersebut merupakan batu gamping napalan tufan yang berstruktur masif dan berporositas baik.

\section{KESIMPULAN}

Dari hasil pengolahan, analisis dan interpretasi data pada penelitian dapat diambil kesimpulan bahwa struktur batuan bawah permukaan di daerah Pamah Paku memiliki nilai resistivitas antara $0 \Omega m$ hingga $10000 \Omega \mathrm{m}$. Nilai resistivitas tinggi diduga sebagai batu gamping sedangkan keterdapatan anomali rendah pada daerah tersebut diduga sebagai sebaran air tanah yang dapat ditemukan pada kedalaman 6 meter hingga 28 meter di jarak yang berbeda-beda dan pola sebaran air bawah permukaan tersebut umumnya dari Selatan ke Utara. Penyebaran batuan bawah permukaan untuk daerah Pamah Paku didominasi oleh batuan tufa sedangkan untuk batu gamping terdapat di kedalaman 15 meter hingga 28 meter.

\section{DAFTAR PUSTAKA}

Cameron et. al., (1982), Geologic Map Of The Medan Quadrangle, Sumatra, Badan Koordinasi Survey dan Pemetaan Nasional, Indonesia.

Endarto Danang, (2005), Pengantar Geologi Dasar, Cetakan 2, LPP UNS dan UPT Press, Surakarta.

Karunia Dimas Noer, Darsono, Darmanto, (2012), Identifikasi Pola Aliran Sungai Bawah Tanah di Mudal, Pracimantoro Dengan Metode Geolistrik, Indonesian Journal of Applied Physics (2012) Vol.2 No.2.

Milsom John Reynolds, (2003), An Introduction to Applied and Environmental Geophysics, Wiley, England.

Pohan Maulana. (2009), Laporan Akhir Kajian Potensi Sumberdaya Mineral di Kawasan Hutan Lindung di Sumatera Utara, Badan Penelitian dan Pengembangan, Sumatera Utara. 